\title{
Agronomic performance of sweet potato crop in succession to leguminous plants in monocropping and intercropped with corn
}

\author{
Jhonatan M Goulart ${ }^{1} \mathbb{D}$; Adriano A Rocha ${ }^{1} \mathbb{D}$; José Antonio A Espindola ${ }^{2} \mathbb{D}$; Ednaldo da S Araújo 2 ${ }^{\mathbb{D}}$; José \\ Guilherme M Guerra ${ }^{2} \mathbb{D}$
}

${ }^{1}$ Universidade Federal Rural do Rio de Janeiro (UFRRJ), Seropédica-RJ, Brasil; marinsgoulart@ymail.com; adriano_vest@hotmail.com; ${ }^{2}$ Embrapa Agrobiologia, Seropédica-RJ, Brasil; jose.espindola@embrapa.br; ednaldo.araujo@embrapa.br; guilherme.guerra@embrapa.br

\begin{abstract}
This study aimed to evaluate sweet potato performance in succession to annual herbaceous leguminous plants, in monocropping or intercropped with corn, under agroecological management, under Baixada Fluminense conditions. The experimental design was randomized blocks, with five treatments and four replicates. The treatments consisted of pre-cropping with the following species: crotalária (Crotalaria juncea) under monocropping system, crotalária intercropped with corn (Zea mays), jack bean (Canavalia ensiformis) under monocropping system, jack bean intercropped with corn and spontaneous vegetation. The results showed that monocropped crotalária reached the greatest dry biomass accumulation during two consecutive years of succession. In the second year, this treatment provided greater accumulated amounts of $\mathrm{N}, \mathrm{K}$ and $\mathrm{Mg}$ in plant biomass. Growing sweet potatoes in succession to the pre-cropping of crotalária is advantageous, as it provided an increase in vegetable productivity in the second year of succession.
\end{abstract}

Keywords: Ipomoea batatas, Crotalaria juncea, Canavalia ensiformis, Zea mays, green manuring, organic agriculture.

\section{RESUMO}

Desempenho agronômico de batata-doce em sucessão a leguminosas em monocultivo ou consorciadas ao milho

O objetivo deste estudo foi determinar o desempenho de batatadoce em sucessão a leguminosas herbáceas anuais, em monocultivo ou consorciadas com milho, sob manejo agroecológico, em condições da Baixada Fluminense. O delineamento experimental empregado foi de blocos ao acaso, com cinco tratamentos e quatro repetições. Os tratamentos envolveram pré-cultivos com as seguintes espécies: crotalária (Crotalaria juncea) em monocultivo, crotalária consorciada ao milho (Zea mays), feijão-de-porco (Canavalia ensiformis) em monocultivo, feijão-de-porco consorciado ao milho e vegetação espontânea. Os resultados demonstraram que a crotalária em monocultivo apresentou maior acúmulo de biomassa seca em dois anos consecutivos da sucessão. No segundo ano, esse tratamento proporcionou maiores quantidades acumuladas de $\mathrm{N}, \mathrm{K}$ e $\mathrm{Mg}$ na biomassa vegetal. $\mathrm{O}$ cultivo de batata-doce em sucessão ao pré-cultivo de crotalária é vantajoso, pois proporcionou aumento de produtividade da hortaliça no segundo ano da sucessão.

Palavras-chave: Ipomoea batatas, Crotalaria juncea, Canavalia ensiformis, Zea mays, adubação verde, agricultura orgânica.

Received on April 7, 2021; accepted on May 4, 2021

$\mathrm{S}^{\mathrm{s}}$ weet potato (Ipomoea batatas) is a vegetable which belongs to botanical family Convolvulaceae. It is from Central and South Americas, where approximately 50 genera and more than 1,000 species can be found (Lebot, 2009). This crop plant is grown in all Brazilian states, using intense tillage, involving plowing and harrowing (Rós, 2017). Propagation is carried out through vine from healthy plants and planting, in general, performed in windrows to make it easy for rooting and harvest.

According to IBGE (2018), the planting area in Brazil covers approximately 53,024 hectares, with an average yield of $13.99 \mathrm{tha}^{-1}$. In Brazil, South and Northeast Regions show the largest planted areas, whereas the Midwest region has the smallest cultivated area. In relation to consumption, in Brazil, sweet potato is the fourth most consumed vegetable, showing a great social importance since it is an energy-rich, high-complex carbohydrate food (Leonardo et al., 2014).

The investment on sweet potato crop is low. The lack of investment in technology is justified by the fact that this is a low profit margin crop, due to its small individual production volume (Silva et al., 2008). The same authors point out that producers still tend to cultivate sweet potatoes as a marginal crop, with the reasoning that, spending the minimum, whatever the crop produces, it represents an additional gain.

Results obtained from some studies, carried out throughout the years, show the productive potential of this crop when submitted to organic fertilization. Santos et al. (2010), evaluating the effect of organic fertilization on sweet potato total production, concluded that total production $\left(18.03 \mathrm{t} \mathrm{ha}^{-1}\right)$ of sweet potato 
roots responded linearly and positively to increasing doses of poultry litter and that fertilizer application increased the total production of sweet potato roots.

Rós et al. (2014), studying the influence of the use of fertilizer sources and doses in sweet potato productivity, verified that the crop responds to soil fertilization, with increases in total and commercial productivity through application of biofertilizers and poultry manure, as well as the combination of both fertilizers. Leonardo et al. (2014) also reported that fertilizing with bovine manure increased $\mathrm{N}$ efficiency, the characteristics of sweet potato production, besides the fact that the combined application of $\mathrm{N}$ top-dressing and bovine manure increased the commercial sweet potato productivity in $5.7 \mathrm{tha}^{-1}$ of roots, when compared with plantation without any nutrient inputs.

Another management system which favors sweet potato productivity and other crops of economic interest is cultivation in succession with green manure. Green fertilizer contributes to improving or maintaining the soil fertility, increasing organic matter level throughout the years (Silva et al., 2014). This management provides $\mathrm{N}$ to the system when the area was previously cultivated with legume (Pereira et al., 2013), giving soil greater resistance against agents which can cause erosion (Teodoro et al., 2011), as it also can reduce incidence of nematodes (Dias et al., 2010).

Green manure using green velvet (Mucuna pruriens var. utilis) provides an increase in agronomic performance of cabbage, submitted to organic management, when compared with corn pre-cropping, considering this management able to substitute organic top-dressing fertilization with no decrease in the vegetable productivity (Cordeiro et al., 2018).

In order to evaluate the performance of sweet potato in corn succession intercropped with legumes, Risso (2007) verified that sweet potato production was not influenced by the presence of legumes grown with corn. However, an increased supply of organic matter and incorporation of $\mathrm{N}$ in the system was verified. In another study, Espindola et al. (1998) observed an increase in sweet potato productivity when grown in succession with velvet bean cultivation. They also observed greater amount of accumulated doses of N, P and $\mathrm{K}$ in the shoots of jack bean and velvet bean in relation to other pre-cropping.

In this context, this study aimed to determine the performance of sweet potato in succession to annual herbaceous legumes, in monocropping or intercropped with corn in an agroecological management system.

\section{MATERIAL AND METHODS}

The experiment was carried out at Embrapa Agrobiologia experimental field, located in the municipality of Seropédica, in the Metropolitan Region of Rio de Janeiro $\left(22^{\circ} 46^{\prime} \mathrm{S}\right.$, $43^{\circ} 41^{\prime} \mathrm{W}, 33 \mathrm{~m}$ altitude). The soil in the experimental area was classified as Red Yellow Argisol (Santos et al., 2018), the chemical properties in 0 to $20 \mathrm{~cm}$ layer are: $\mathrm{pH}=5.78 ; \mathrm{Al}^{+++}=0.0 \mathrm{cmol}_{\mathrm{c}} /$ $\mathrm{dm}^{-3} ; \mathrm{P}=44.94 \mathrm{mg} / \mathrm{L} ; \mathrm{K}=31,00 \mathrm{mg} / \mathrm{L}$; $\mathrm{Ca}=1.86 \mathrm{cmol}_{\mathrm{c}} / \mathrm{dm}^{-3}$; and $\mathrm{Mg}=0.95$ $\mathrm{cmol}_{\mathrm{c}} / \mathrm{dm}^{-3}$, analyzed according to the methodology described by Nogueira \& Souza (2005).

The experimental design used was randomized blocks with five treatments and four replicates. During the two agricultural years, the plots were kept in the same place, with dimensions of $6.5 \times 5.0 \mathrm{~m}$, covering an area of 32.5 $\mathrm{m}^{2}$. Pre-cropping treatments were: spontaneous vegetation, monocropped crotalária (Crotalaria juncea); crotalária intercropped with corn, (Zea mays) monocropped jack bean (Canavalia ensiformis), jack bean intercropped with corn, using BRS Eldorado corn. The spontaneous vegetation in the first year of cultivation consisted mainly of "anileira" (Indigofera hirsuta). In the second year of cultivation, besides the "anileira", the presence of crabgrass (Digitaria horizontalis) and Euphorbia heterophylla (wild poinsettia) was also observed.

Before installation, the experimental area had been under fallow for approximately 10 years. Plowing and harrowing were performed before this experiment installation. Then, furrows (spaced $50 \mathrm{~cm}$ ) were opened. In the two years of agriculture, we performed corn and vegetable sowing at the same time, in November. Corn crop was sown in simple rows alternating with vegetables. The vegetables seeds were inoculated with bacteria of the genus Rhizobium, strain BR 2003 (SEMIA 6156), of the crop collection of Embrapa Agrobiologia, and, then, the seeds were sown in densities of 10-30 seeds per linear meter for jack beans and crotalária, respectively. Corn crop was sown in density of 10 plants per linear meter. Afterwards, these plants were thinned to five plants.

The total area was fertilized at the same time corn and vegetables were sown. We applied $80 \mathrm{~kg} \mathrm{ha}^{-1} \mathrm{P}_{2} \mathrm{O}_{5}$ as thermophosphate source, and $80 \mathrm{~kg}$ ha $^{-1} \mathrm{~K}_{2} \mathrm{O}$, using potassium sulfate. The thermophosphate used in this experiment showed $180 \mathrm{~g} \mathrm{~kg}^{-1}$ and potassium sulfate $480 \mathrm{~g} \mathrm{~kg}^{-1} \mathrm{~K}_{2} \mathrm{O}$.

Among the cultural practices we performed, top-dressing nitrogen doses in the corn crop stood out. We used an equivalent dose of $100 \mathrm{~kg} \mathrm{ha}^{-1} \mathrm{~N}$, in the form of castor cake containing $50 \mathrm{~g} \mathrm{~N}$ $\mathrm{kg}^{-1}$ in the composition, being splitted in two applications, at 15 and 30 days after sowing. The intercropped crotalária was pruned, at 35 days after sowing. Pruning was performed when corn and crotalária reached the same height. The crotalária was pruned at $30 \mathrm{~cm}$ below the main ear insertion or approximately $1 / 3$ of its total height. During pruning, biomass samples were collected in a $2-m^{2}$ useful area $(2 \times 1)$ from the plots of crotalária intercropped with corn, to quantify the fresh biomass productivity obtained from pruning. A subsample was removed and taken to the oven with forced air circulation at $65^{\circ} \mathrm{C}$, to determine dry mass productivity and nutrient content, which were added to the total dry biomass and nutrient accumulation in intercropped crotalária. Cartridge caterpillar (Spodoptera frugiperda) was controlled in the corn crop, by applying Bacillus thuringiensis at $10 \mathrm{~g} \mathrm{~L}^{-1}$ from the first moment the insect was detected.

Corn harvest was done using $6 \mathrm{~m}^{2}$ samples of useful area per plot, collected 
from the two central rows, in order to evaluate green corn productivity. At 120 days after sowing, we collected samples from $2 \mathrm{~m}^{2}$ area per plot $(2 \mathrm{x} 1)$, of corn, intercropped vegetables, monocropped vegetables, and also $1 \mathrm{~m}^{2}$ per plot of spontaneous vegetation, in order to determine the fresh biomass of the species used for pre-cropping, removing one subsample which was taken to an oven with forced air circulation at $65^{\circ} \mathrm{C}$ to determine dry biomass and the nutrient contents. The contents and accumulation of the nutrients were described for spontaneous vegetations and vegetables. The procedure for analyzing $\mathrm{N}$ in the biomass was based on Kjedahl method, $\mathrm{P}$ was analyzed through colorimetric method, $\mathrm{K}$ by flame photometry, $\mathrm{Ca}$ and $\mathrm{Mg}$ were determined by atomic absorption method, according to the procedures described by Nogueira \& Souza (2005).

After collecting samples, in order to determine fresh and dry biomasses, contents and accumulation of nutrients, we cut the pre-cropping and biomass was incorporated to soil with the aid of a harrow. The authors planted the sweet potato one week after the cutting management of the pre-cropping. During the planting, windrows were built in a field measuring 5 meters long, $0.5 \mathrm{~m}$ wide and $0.3 \mathrm{~m}$ high, spacing 1 meter between the windrows, totalizing six windrows per plot. Planting of sweet potato cv. Rosinha do Verdan was performed in March in the two years of agriculture, spacing $20 \mathrm{~cm}$ between vines. Vines were selected through segments of the end of the matrix plant measuring approximately $30 \mathrm{~cm}$ long, from the experimental field of Embrapa Agrobiologia.

The harvest was performed five months after planting, with samples of six square meters per plot, collected from the useful area of the two central windrows of the plots, discarding the border rows. The roots were classified according to the categories proposed by Silva et al. (1991): Extra A (251 to $500 \mathrm{~g}$ ), Extra (151 to $250 \mathrm{~g}$ ), Diverse (80 to $150 \mathrm{~g}$ ) and tubers weighing 10 to $79 \mathrm{~g}$. The roots belonging to Extra and Diverse categories are considered marketable roots.

Dry biomass accumulation data $(\mathrm{t}$ $\left.\mathrm{ha}^{-1}\right)$, contents $\left(\mathrm{g} \mathrm{kg}^{-1}\right)$ and accumulation
( $\mathrm{kg} \mathrm{ha} \mathrm{ha}^{-1}$ ) of the nutrients $\mathrm{N}, \mathrm{P}, \mathrm{K}$, $\mathrm{Mg}$ of the pre-cropping species and productivity of the sweet potato $\left(\mathrm{t} \mathrm{ha}^{-}\right.$ ${ }^{1}$ ), in two years of agriculture (2012 and 2013) were submitted to variance analysis by $\mathrm{F}$ test and the averages were compared using Scott-Knott test $(\mathrm{p} \leq 0.05)$. Pearson's correlation coefficients (r) between the values of the total productivity of sweet potato and macronutrient obtained in two years were also obtained. R software (R Core Team, 2020) was used to perform these analyses.

\section{RESULTS AND DISCUSSION}

Corn intercropped with crotalária obtained productivity of 5.80 and 7.24 $\mathrm{t} \mathrm{ha}^{-1}$ of green ears in the first and in the second years, respectively, whereas corn intercropped with jack beans reached 6.34 and $7.53 \mathrm{t} \mathrm{ha}^{-1}$. These productivities are similar to the ones obtained by Guedes et al. (2010) studying corncowpea intercropping under similar climatic conditions. We highlight that corn crop can be considered one facilitating element during the insertion of green manures, since during this period in addition to the biomass production from legumes and corn, we could also verify green ear production, which allows income earning during the period of green fertilization, without reduction in productivity.

In relation to dry biomass accumulation of green manures, monocropped crotalária reached the highest value of accumulation, in the two years of cultivation, whereas the treatment with spontaneous vegetation showed the lowest value of biomass accumulation (Table 1). We highlight that the spontaneous vegetation, besides presenting less accumulation of biomass, was constituted mainly by anileira (Indigofera hirsuta), which is an herbaceous legume, and also by grasses and euphorbia, which results in an inferior quality biomass comparing with the other treatments. In different populational arrangements, Amabile et al. (2000) reported, for crotalária, dry biomass productivity of $17.26 \mathrm{t}$ $\mathrm{ha}^{-1}$ during spring-summer season, whereas Pereira et al. (2005) obtained, for the same season, $10.7 \mathrm{t} \mathrm{ha}^{-1}$ and in autumn-winter season, $6.8 \mathrm{t} \mathrm{ha}^{-1}$. Other authors showed dry biomass production for this vegetable ranging from $2.64 \mathrm{t} \mathrm{ha}^{-1}$ (Medina et al., 2013) to $9.83 \mathrm{t} \mathrm{ha}^{-1}$ (Suzuki \& Alves, 2006). The results found in literature showed a wide range considering the dry biomass productivity of this vegetable, showing that the biomass can vary in relation to planting season, plant density and cultivation under variable climatic conditions.

The intercropping of crotalária and jack beans with corn, probably due to the lower plant density, resulted in lower biomass productivity in relation to the respective monocropping systems. However, intercropping provides extra income with the production of green ears; this can contribute with green manure management in production units, mainly those ones considered family farms.

Table 1. Total dry biomass accumulation of pre-cropping in two consecutive cycles. Seropédica, Embrapa Agrobiologia, 2012, 2013.

\begin{tabular}{|c|c|c|c|c|c|c|}
\hline \multirow{3}{*}{ Pre-cropping } & \multicolumn{6}{|c|}{ Dry biomass (t ha' $\left.{ }^{-1}\right)$} \\
\hline & \multicolumn{3}{|c|}{$1^{\text {st }}$ year } & \multicolumn{3}{|c|}{$2^{\text {nd }}$ year } \\
\hline & Vegetables & Corn & Total & Vegetables & Corn & Total \\
\hline Spontaneous & 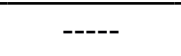 & 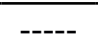 & $4.79 \mathrm{C}^{1}$ & $\begin{array}{l}---- \\
-\end{array}$ & 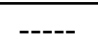 & $2.37 \mathrm{D}$ \\
\hline Crotalária & 13.04 & ----- & $13.04 \mathrm{~A}$ & 15.84 & ----- & $15.84 \mathrm{~A}$ \\
\hline Crotalária + corn & 6.04 & 4.74 & $10.78 \mathrm{~B}$ & 8.15 & 3.68 & $11.84 \mathrm{~B}$ \\
\hline Jack beans & 9.43 & ---- & $9.43 \mathrm{~B}$ & 11.75 & ----- & $11.75 \mathrm{~B}$ \\
\hline Jack beans + corn & 4.87 & 4.79 & $9.66 \mathrm{~B}$ & 4.38 & 3.31 & $7.70 \mathrm{C}$ \\
\hline $\mathrm{CV}(\%)$ & $\begin{array}{ll}---- \\
--\end{array}$ & $\begin{array}{ll}---- \\
--\end{array}$ & 14.05 & $\begin{array}{ll}---- \\
--1\end{array}$ & $\begin{array}{ll}---- \\
-\cdots\end{array}$ & 22.96 \\
\hline
\end{tabular}

${ }^{1}$ Averages followed by the same letter do not differ from each other by the Scott-Knott test at $5 \%$ probablility. 
The nutrient contents present in dry biomass of vegetables and spontaneous vegetation did not differ in the first year for $\mathrm{N}$ and $\mathrm{K}$. Contents of $\mathrm{P}$ and $\mathrm{Ca}$ were superior in treatments with monocropped jack beans and jack beans intercropped with corn, (Zea mays) though. Jack bean pre-cropping intercropped with corn and spontaneous vegetation showed higher values for $\mathrm{Mg}$ contents (Table 2). We highlight that, probably, no difference in $\mathrm{N}$ contents between spontaneous vegetation and vegetables was noticed, due to the predominance of anileira as
Table 2. Nutrient contents in the shoot part of vegetables and spontaneous vegetation obtained in two consecutive cycles. Seropédica, Embrapa Agrobiologia, 2012, 2013.

\begin{tabular}{|c|c|c|c|c|c|}
\hline \multirow{2}{*}{ Pre-cropping } & \multicolumn{5}{|c|}{ Nutrient contents in biomass $\left(\mathrm{g} \mathrm{kg}^{-1}\right)\left(1^{\text {st }}\right.$ year $)$} \\
\hline & $\mathbf{N}$ & $\mathbf{P}$ & $\mathbf{K}$ & $\mathbf{C a}$ & Mg \\
\hline Spontaneous & $17.7 \mathrm{~A}^{1}$ & $1.67 \mathrm{~B}$ & $16.37 \mathrm{~A}$ & $11.13 \mathrm{~B}$ & $3.33 \mathrm{~A}$ \\
\hline Crotalária & $17.2 \mathrm{~A}$ & $1.22 \mathrm{~B}$ & $10.31 \mathrm{~A}$ & $4.46 \mathrm{C}$ & $2.17 \mathrm{~B}$ \\
\hline Crotalária + corn & $19.3 \mathrm{~A}$ & $1.60 \mathrm{~B}$ & $12.68 \mathrm{~A}$ & $5.36 \mathrm{C}$ & $2.51 \mathrm{~B}$ \\
\hline Jack beans & $27.2 \mathrm{~A}$ & $2.15 \mathrm{~A}$ & $15.25 \mathrm{~A}$ & $15.80 \mathrm{~A}$ & $2.27 \mathrm{~B}$ \\
\hline Jack beans + corn & $21.9 \mathrm{~A}$ & $2.07 \mathrm{~A}$ & $9.93 \mathrm{~A}$ & $18.95 \mathrm{~A}$ & $3.47 \mathrm{~A}$ \\
\hline \multirow[t]{2}{*}{ CV $(\%)$} & 34.25 & 18.03 & 30.70 & 24.38 & 25.42 \\
\hline & \multicolumn{5}{|c|}{ Nutrient contents in biomass $\left(\mathrm{g} \mathrm{kg}^{-1}\right)\left(2^{\text {nd }}\right.$ year $)$} \\
\hline Spontaneous & $13.0 \mathrm{~B}$ & $1.70 \mathrm{~A}$ & $15.06 \mathrm{~A}$ & $6.0 \mathrm{~B}$ & $4.66 \mathrm{~A}$ \\
\hline Crotalária & $24.9 \mathrm{~A}$ & $1.68 \mathrm{~A}$ & $8.37 \mathrm{~A}$ & $9.66 \mathrm{~B}$ & $5.16 \mathrm{~A}$ \\
\hline Crotalária+corn & $24.1 \mathrm{~A}$ & $1.72 \mathrm{~A}$ & $9.37 \mathrm{~A}$ & $10.18 \mathrm{~B}$ & $4.75 \mathrm{~A}$ \\
\hline Jack beans & $21.2 \mathrm{~A}$ & $1.57 \mathrm{~A}$ & $7.25 \mathrm{~B}$ & $12.91 \mathrm{~B}$ & $2.56 \mathrm{~B}$ \\
\hline Jack beans + corn & $22.2 \mathrm{~A}$ & $1.76 \mathrm{~A}$ & $8.68 \mathrm{~B}$ & $20.55 \mathrm{~A}$ & $3.92 \mathrm{~A}$ \\
\hline CV (\%) & 41.26 & 18.12 & 28.46 & 26.10 & 14.59 \\
\hline
\end{tabular}

${ }^{1}$ Averages followed by the same letter do not differ from each other by the Scott-Knott test at $5 \%$ probablility.

Table 3. Nutrient accumulation in the shoot part of vegetables and spontaneous vegetation obtained in two consecutive cycles. Seropédica, Embrapa Agrobiologia, 2012, 2013.

\begin{tabular}{|c|c|c|c|c|c|}
\hline \multirow{2}{*}{ Pre-cropping } & \multicolumn{5}{|c|}{ Nutrient accumulation $\left(\mathrm{kg} \mathrm{ha}^{-1}\right)\left(1^{\text {st }}\right.$ year $)$} \\
\hline & $\mathbf{N}$ & $\mathbf{P}$ & $\mathbf{K}$ & $\mathbf{C a}$ & Mg \\
\hline Spontaneous & $84.87 \mathrm{~B}^{1}$ & $7.83 \mathrm{~B}$ & $77.88 \mathrm{~B}$ & $51.62 \mathrm{~B}$ & $15.85 \mathrm{~A}$ \\
\hline Crotalária & $223.45 \mathrm{~A}$ & $15.79 \mathrm{~A}$ & $133.24 \mathrm{~A}$ & $57.37 \mathrm{~B}$ & $28.12 \mathrm{~A}$ \\
\hline Crotalária+corn & $115.12 \mathrm{~B}$ & $9.51 \mathrm{~B}$ & $74.32 \mathrm{~B}$ & $31.39 \mathrm{~B}$ & $15.15 \mathrm{~A}$ \\
\hline Jack beans & $250.59 \mathrm{~A}$ & $20.21 \mathrm{~A}$ & $139.65 \mathrm{~A}$ & $151.60 \mathrm{~A}$ & $21.48 \mathrm{~A}$ \\
\hline Jack beans + corn & $112.77 \mathrm{~B}$ & $10.47 \mathrm{~B}$ & $47.18 \mathrm{~B}$ & $93.55 \mathrm{~B}$ & $17.47 \mathrm{~A}$ \\
\hline \multirow[t]{2}{*}{ CV $(\%)$} & 40.58 & 27.40 & 26.29 & 41.23 & 32.32 \\
\hline & \multicolumn{5}{|c|}{ Nutrient accumulation $\left(\mathrm{kg} \mathrm{ha}^{-1}\right)\left(2^{\text {nd }}\right.$ year $)$} \\
\hline Spontaneous & $30.08 \mathrm{C}$ & $4.25 \mathrm{C}$ & $33.62 \mathrm{C}$ & $14.07 \mathrm{C}$ & $11.30 \mathrm{C}$ \\
\hline Crotalária & $381.90 \mathrm{~A}$ & $25.79 \mathrm{~A}$ & $130.20 \mathrm{~A}$ & $148.70 \mathrm{~A}$ & $79.70 \mathrm{~A}$ \\
\hline Crotalária + corn & $199.70 \mathrm{~B}$ & $14.25 \mathrm{~B}$ & $75.39 \mathrm{~B}$ & $85.00 \mathrm{~B}$ & $39.31 \mathrm{~B}$ \\
\hline Jack beans & $244.60 \mathrm{~B}$ & $18.40 \mathrm{~A}$ & $80.17 \mathrm{~B}$ & $148.9 \mathrm{~A}$ & $30.36 \mathrm{~B}$ \\
\hline Jack beans + corn & $98.25 \mathrm{C}$ & $7.68 \mathrm{C}$ & $35.79 \mathrm{C}$ & $91.99 \mathrm{~B}$ & $17.61 \mathrm{C}$ \\
\hline CV $(\%)$ & 33.32 & 22.69 & 23.79 & 32.31 & 25.61 \\
\hline
\end{tabular}

${ }^{1}$ Averages followed by the same letter do not differ from each other by the Scott-Knott test at $5 \%$ probablility.

Horticultura Brasileira 39 (2) April - June, 2021 a component of spontaneous vegetation in the experimental area. Cavalcante $e t$ al. (2012), studying different vegetables, verified that no difference regarding to $\mathrm{N}$ contents was observed. These values were superior to spontaneous vegetation, though. In the second year of cultivation, higher $\mathrm{N}$ contents were observed in monocropped vegetables and intercropped with corn, in relation to spontaneous vegetation, as well as, higher $\mathrm{Ca}$ contents in jack beans intercropped with corn. The highest $\mathrm{K}$ contents were associated with treatments with monocropped crotolária, crotalária intercropped with corn and spontaneous vegetation. $\mathrm{Mg}$ content was inferior in dry biomass of jack beans when intercropped with corn. Similar results of macronutrient levels in different kinds of green manures in monocropping or intercropping systems were described by Rodrigues et al. (2012). Cavalcante et al. (2012), studying under different climatic conditions, obtained similar results for all macronutrients which did not differ statistically, except for $\mathrm{Ca}$, which showed a higher content in the dry biomass of the jack bean.

In relation to accumulated macronutrients in dry biomass of vegetables and spontaneous vegetation, the authors verified that, in the first year, treatments crotalária and jack beans under monocropping system showed higher quantities of N, P and K, whereas monocropped jack beans provided higher quantity of accumulated $\mathrm{Ca}$. In the second cultivation cycle, the authors observed that pre-cropping of monocropped crotalária showed, when compared with other treatments, higher quantities of $\mathrm{N}, \mathrm{K}$ and $\mathrm{Mg}$ accumulated in the biomass, whereas for $\mathrm{P}$ and $\mathrm{Ca}$, higher accumulated quantities were observed in monocropped crotalária and jack beans (Table 3). Jack bean is a species which tends to show a higher $\mathrm{Ca}$ accumulation, which is confirmed by the results described by Heinrichs et al. (2005) in two cycles, obtaining superior accumulated quantities of $\mathrm{Ca}$ when compared with other precropped species. Similar results were described by Padovan et al. (2011), showing that even from flowering, jack bean accumulates significant amounts of biomass and nutrients, mainly N, K 
and $\mathrm{Ca}$.

In relation to total and marketable productivity of sweet potato (Figure 1), the authors observed high productivity in all treatments in the first year of cultivation. That may have happened due to the fact that this area had been in extended fallow period, approximately 10 years, before the experiment installation. In the second year of cultivation, the authors observed that the treatment with monocropped crotalária provided the best performance of the sweet potato, reaching a productivity of

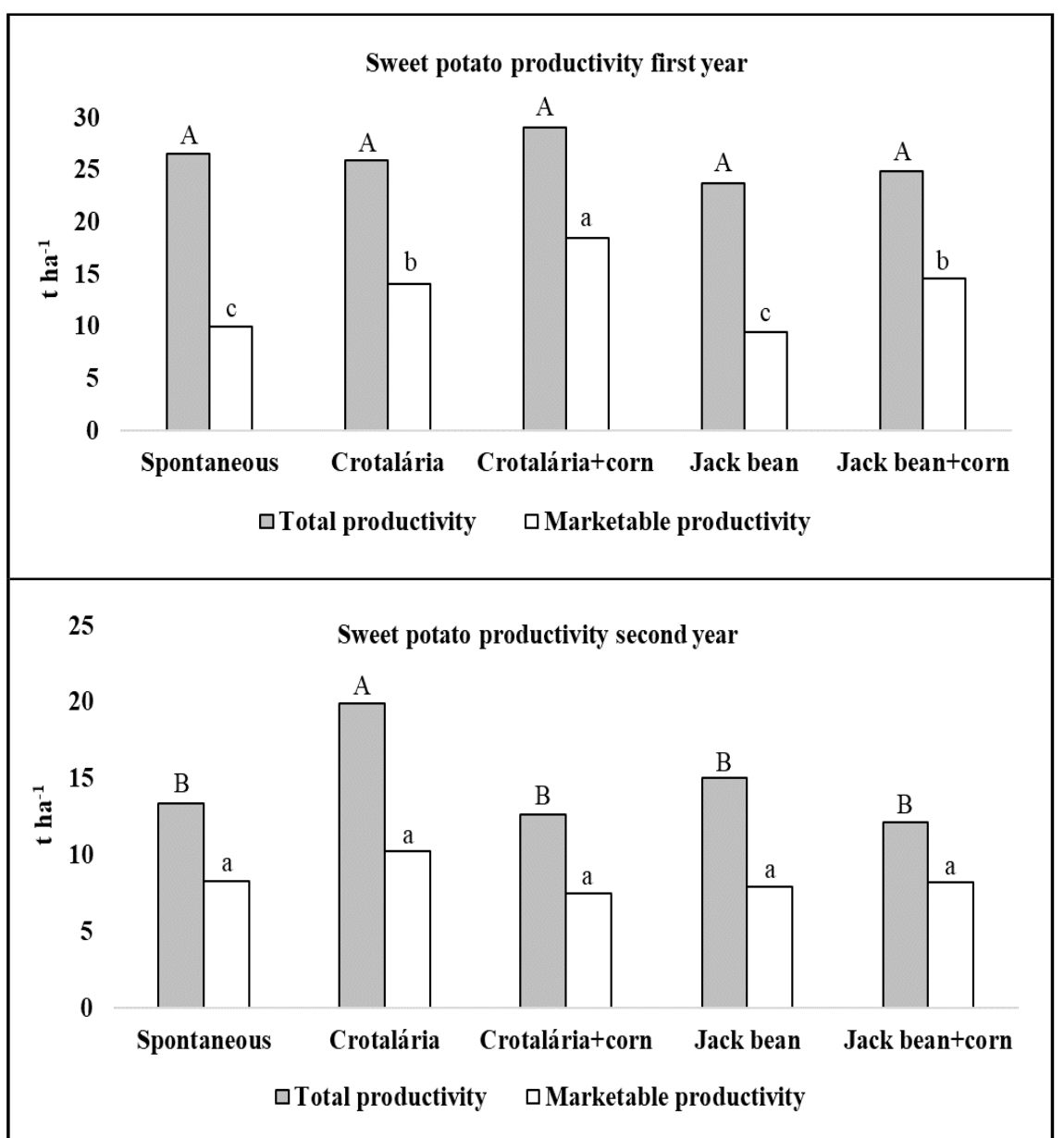

Figure 1. Total and marketable productivity of sweet potato obtained in two consecutive cycles. Averages followed by the same letter, uppercase for total productivity and lowercase for marketable productivity do not differ from each other by the Scott-Knott test at 5\% probablility. Seropédica, Embrapa Agrobiologia, 2012, 2013.

Table 4. Pearson's correlation coefficients (r) which relate the macronutrients accumulated by green manures with the total productivity of sweet potatoes in two consecutive cycles. Seropédica, Embrapa Agrobiologia, 2012, 2013.

\begin{tabular}{ccccc}
\hline Macronutrient & Year 1 & $\begin{array}{c}\text { Probability of } \\
\text { significance }\end{array}$ & Year 2 & $\begin{array}{c}\text { Probability of } \\
\text { significance }\end{array}$ \\
\hline $\mathrm{N}$ & 0.56 & 0.3247 & $0.85^{* *}$ & 0.0714 \\
$\mathrm{P}$ & 0.66 & 0.2266 & $0.85^{* *}$ & 0.0689 \\
$\mathrm{~K}$ & 0.38 & 0.5244 & $0.89^{*}$ & 0.0438 \\
$\mathrm{Ca}$ & $0.89^{*}$ & 0.0441 & 0.62 & 0.2633 \\
$\mathrm{Mg}$ & 0.43 & 0.4667 & $0.88^{*}$ & 0.0431 \\
\hline
\end{tabular}

Probability of significance: *significant values at $5 \%$ and $* *$ significant values at $10 \%$.

19.9 tha $^{-1}$. Similar result was reported by Souza et al. (2019) under similar climatic conditions and with the same cultivar. Quantifying performance of fourteen accessions of sweet potato evaluated in four different environments, Daros \& Amaral Júnior (2000) obtained, for cultivar Rosinha do Verdan, maximum productivity of $24.1 \mathrm{tha}^{-1}$ and minimum of $9.25 \mathrm{tha}^{-1}$.

Correlation analysis showed that in the first year of cultivation, $\mathrm{Ca}$ showed positive correlations with total productivity of sweet potato, whereas, in the second year of cultivation, macronutrients $\mathrm{K}$ and $\mathrm{Mg}$ correlated positively with the total sweet potato productivity, allowing the authors to infer that the supply of these nutrients was one of the factors which were responsible for the beneficial effect on the productive yield of this vegetable in the second year of succession (Table 4). Espindola et al. (1998) verified positive correlations between sweet potato production and quantities of nutrients provided by pre-croppings, mainly when pre-cropping with velvet bean, which ensured greater supply of $\mathrm{N}$ and recycling of $\mathrm{P}$ and $\mathrm{K}$, reaching an estimated sweet potato yield of $20 \mathrm{tha}^{-1}$ under similar climatic conditions.

In relation to marketable productivity, the authors observed that crotalária intercropped with corn provided higher productivity of marketable-standard tubers in the first year; no difference was noticed in the second year of cultivation.

Considering the obtained data, monocropped crotalária obtained the highest productivity of dry biomass in the two consecutive cycles. In the second year of succession, it showed higher accumulated amounts of N, K and $\mathrm{Mg}$ in plant biomass. The cultivation of sweet potatoes in succession to the precropping of crotalária is advantageous, as it provided an increase in vegetable productivity in the second year of succession.

The authors highlight the advantages of intercropping crops for organic agriculture management, as in addition to the production of biomass of the two species, the farmers can obtain additional income from the production of green ears, which may contribute 
to the adoption of green manure in production units.

\section{REFERENCES}

AMABILE, RF; FANCELLI, AL; CARVALHO, AM. 2000. Comportamento de espécies de adubos verdes em diferentes épocas de semeadura e espaçamentos na Região dos Cerrados. Pesquisa Agropecuária Brasileira 35: 47-54.

CAVALCANTE, VS; SANTOS, VR; SANTOS NETO, AL; SANTOS, MAL; SANTOS, CG; COSTA, LC. 2012. Biomassa e extração de nutrientes por plantas de cobertura. Revista Brasileira Engenharia Agrícola Ambiental 16: 521-528.

CORDEIRO, AAS; RODRIGUES, MB; GONÇALVES JÚNIOR, M; ESPINDOLA, JAA; ARAÚJO, ES; GUERRA, JGM. 2018. Organic cabbage growth using green manure in pre-cultivation and organic top dressing fertilization. Horticultura Brasileira 36: 515-520.

DAROS, M; AMARAL JUNIOR, AT. 2000. Adaptabilidade e estabilidade de produção de Ipomoea batatas. Acta Scientiarum. Agronomy 22: 911-917.

DIAS, WP; GARCIA, A; SILVA, JFV; CARNEIRO, GES. Nematoides em soja: identificação e controle. Londrina: Embrapa Soja. 2010. 8p. (Embrapa Soja. Circular Técnica, 76).

ESPINDOLA, JAA; ALMEIDA, DL; GUERRA, JGM; SILVA, EMR; SOUZA, FA. 1998. Influência da adubação verde na colonização micorrízica e a produção de batata-doce. Pesquisa Agropecuária Brasileira 33: 339347.

GUEDES, RE; RUMJANEK, NG; XAVIER, GR; GUERRA, JGM; RIBEIRO, RL. 2010. Consórcios de caupi e milho em cultivo orgânico para produção de grãos e espigas verdes. Horticultura Brasileira 28: 174-177.

HEINRICHS, R; VITTI, GC; MOREIRA, A; FIGUEIREDO, PAM; FANCELLI, AL; CORAZZA, EJ. 2005. Características químicas de solo e rendimento de fitomassa de adubos verdes e de grãos de milho, decorrente do cultivo consorciado. Revista Brasileira de Ciência do Solo 29: 71-79.

INSTITUTO BRASILEIRO DE GEOGRAFIA E ESTATÍSTICA. IBGE. 2018. Produção
Agrícola Lavoura Temporária. Available https://cidades.ibge.gov.br/brasil/ pesquisa/14/0?indicador $=10267$. Accessed September 9, 2020.

LEBOT, V. 2009. Tropical root and tuber crops: Cassava, sweet potato, yams and aroids, Crop prodution science in horticulture. Oxfordshire: CABI, 432p.

LEONARDO, FAP; OLIVEIRA, AP; PEREIRA, WE; SILVA, OPR; BARROS, JRA. 2014. Rendimento de batata-doce adubada com $\mathrm{N}$ e esterco bovino. Revista Caatinga 27: 18-23.

MEDINA, CC; NEVES, CSVJ; AITA, C; BORDIN, I; PRETI, E; ZACCHEO, PVC; AGUIAR, RS; URQUIAGA, S. 2013. Aporte de matéria seca por raízes e parte aérea de plantas de cobertura de verão. Ciências Agrárias 34: 675-682.

NOGUEIRA, AR; SOUZA, GB. 2005. Manual de laboratórios: Solo, água, nutrição vegetal, nutrição animal e alimentos. São Carlos: Embrapa Pecuária Sudeste. 313p.

PADOVAN, MP; MOTTA, IS; CARNEIRO, LF; MOITINHO, MR; FERNANDES, SSL. 2011. Acúmulo de fitomassa e nutrientes e estádio mais adequado de manejo do feijão-de-porco para fins de adubação verde. Revista Brasileira de Agroecologia 6: 182-190.

PEREIRA, AJ; GUERRA, JGM; MOREIRA, VF; TEIXEIRA, MG; URQUIGA, S; POLIDOR, JC; ESPINDOLA, JAA. 2005. Desempenho agronômico de crotalária juncea em diferentes arranjos populacionais e épocas do ano. Comunicado técnico 82, Embrapa Agrobiologia, 4p.

PEREIRA, NS; SOARES, I; PEREIRA, ESS. 2013. Uso de leguminosas como fonte alternativa de $\mathrm{N}$ nos agroecossistemas. Revista Verde de Agroecologia e Desenvolvimento Sustentável 7: 36-40.

R Core Team. 2020. R: A language and environment for statistical computing. $\mathrm{R}$ Foundation for Statistical Computing, Vienna, Austria. URL https://www.R-project.org/.

RISSO, IAM. 2007. Cultivo de batata-doce (Ipomoea L.) em sucessão ao milho (Zea mays L.) consorciado com leguminosas para adubação verde, sob manejo orgânico de produção. Seropédica: UFRRJ. 40p. (M.Sc. dissertation).

RODRIGUES, GB; SÁ, ME; VALÉRIO FILHO, WV; BUZETTI, S; BERTOLIN, DC; PINA, TP. 2012. Matéria e nutrientes da parte aérea de adubos verdes em cultivos exclusivo e consorciado. Revista Ceres 59: 380-385.

RÓS, AB. Sistemas de preparo do solo para o cultivo da batata-doce. 2017. Bragantia 76: 113-124.

RÓS, AB; NARITA, N; HIRATA, ACS. 2014. Produtividade de batata-doce e propriedades físicas e químicas de solo em função de adubação orgânica e mineral. Semina. Ciências Agrárias 35: 205-214.

SANTOS, HG; JACOMINE, PKT; ANJOS, LHC; OLIVEIRA, VA; LUMBRERAS, JF; COELHO, MR; ALMEIDA, JA; ARAUJOFILHO, JC; OLIVEIRA, JB; CUNHA, TJF. 2018. Sistema Brasileiro de Classificação de Solos. 5.ed., Brasília, DF: Embrapa, 353p.

SANTOS, JF; BRITO, CH; SANTOS, MCCA. 2010. Avaliação da produção de batata-doce em função de níveis de adubação orgânica. Acta Scientiarum Agronomy 32: 663-666. SILVA, EC; AMBROSANO, EJ; SCIVITTARO, WB; MURAOKA, T; BUZETTE, S; CARVALHO, AMDE. 2014. Adubação verde como fonte de nutrientes as culturas. In: LIMA FILHO, OF AMBROSANO, EJ; ROSSI, F; CARLOS, JAD (eds). Adubação verde e plantas de cobertura no Brasil: Fundamentos e práticas. p.267-305.

SILVA, JBC; LOPES, CA; MAGALHÃES, JS. 2018. Batata-doce (Ipomoea batatas). Available https://sistemasdeproducao.cnptia. embrapa.br/FontesHTML/Batata-doce/Batatadoce_Ipomoea_batatas/autores.htm. Accessed August 31, $20 \overline{18 .}$

SILVA, JLO; CALBO, AG; HENZ, GP. 1991. Classificação e beneficiamento de hortaliças. Informe Agropecuário 15: 48-53.

SOUZA, JR.; MAGALHAES, RS; RIBEIRO, BN; MINGOTTE, FLC; CASTRO, GSA; GUERRA, JGM; ESPINDOLA, JAA. 2019. Desempenho agronômico da batata-doce em sucessão a milho e crotalária inoculados com fungos micorrízicos. Science and Technology Innovation in Agronomy 3: 106-114.

SUZUKI, LEAS; ALVES, MC. 2006. Fitomassa de plantas de cobertura em diferentes sucessões de culturas e sistemas de cultivo. Bragantia 65 : 121-127.

TEODORO, RB; OLIVEIRA, FL; SILVA, DMN, FÁVERO, C; QUARESMA, MAL. 2011. Aspectos agronômicos de leguminosas para adubação verde no Cerrado do Alto Vale do Jequitinhonha. Revista Brasileira de Ciência do Solo 35: 635-643. 